\title{
The evolution of gendered migration trajectories from Moldova \& Georgia
}

\author{
Michaella Vanore and Melissa Siegel
}

\author{
* Correspondence: \\ melissa.siegel@maastrichtuniversity.nl \\ Maastricht University, Maastricht \\ Graduate School of Governance, \\ Maastricht, The Netherlands
}

\begin{abstract}
This paper is the first of its kind to comparatively examine the evolution of feminized migration flows from Moldova and Georgia in the post-Soviet period. Despite some similarities between the two countries, unique migration patterns have emerged from each as the result of the complex interplay among social, political, and economic transitions. Changing labour market needs in receiving countries coupled with evolving political relationships with neighbouring countries have moulded gendered migration processes in each country. Using household survey data collected between 2011-2012 in Moldova and Georgia, this paper adds to the sparse data availability on the subject and finds that women have not only begun entering international migration at relatively high rates, but their dispersion across a larger number of destination countries and employment sectors than men suggests greater diversification among female migrants. Such evolving dynamics are important to understand for both Moldova and Georgia, which have experienced the loss of 25 per cent of their populations to migration over the past two decades.

JEL codes: F22, F66, J61, J16.

Keywords: Migration; Feminization; Transition; Moldova; Georgia
\end{abstract}

\section{Introduction}

The collapse of the Soviet Union introduced unprecedented opportunities for personal mobility, yet in the twenty years since the onset of the post-Soviet transition, quantification of the scale and nature of emigration from many former republics is lacking. Moldova and Georgia are no exceptions; both states are thought to have lost significant shares of their population to migration, and in recent years the composition of emigration flows is thought to have shifted to include more women. This last assumption has inspired strong public discourses that assert that women have started emigrating en masse, with female mobility perceived as particularly problematic for maintaining family life (Panțîru, Black, and Sabates-Wheeler, 2007; Hofmann and Buckley, 2013). These discourses have been accompanied by little consistent evidence, however, to either confirm or contest changes in the composition of migrant flows. The purpose of this paper is therefore two-fold: 1 ) to provide a descriptive overview of how the mobility patterns of men and women have changed over time, and 2) to explore the factors that influence particular migration patterns. 
Several problems plague the collection of migration data from post-Soviet states. Much data on emigration is collected from immigration-by-origin data in receiving states, but differing definitions of migration and the presence of large irregular migrant populations can imply that migrant populations are enumerated inconsistently across states. Population censuses conducted in migrant-sending states can provide potentially more accurate estimations than immigration-by-origin data, but their infrequent collection makes it difficult to capture fluctuating population movements that are typical of transitional economies. More frequently-conducted household surveys such as household budget surveys (HBS) and labour force surveys (LFS) are valuable alternatives to censuses, but additional care in sampling must be taken to ensure that information on relatively rare events such as migration can be captured without compromising the statistical validity of results (Makaryan, 2012).

The above constraints have resulted in a marked lack of reliable, gender disaggregated emigration data from Moldova and Georgia, which is especially problematic given the increased focus on emigration in both public discourses and policy. In Moldova, emigration data is collected and disseminated on a monthly basis (NBS, 2012) but is derived from civil registration systems, which provide limited detail on migration episodes and only capture individuals as international migrants given a registered change in residence for six months or longer (Makaryan, 2012). The quarterly LFS contains some migration indicators but collects limited information on individual migration trajectories. Several independent data collection initiatives-such as periodic surveys among migrants conducted by the International Agency for Source Country Information (IASCI) and the Centre of Sociological, Politological and Psychological Analysis and Investigations (CIVIS) - have provided more detailed data but often collected data only on migration of 12 months or longer. In Georgia data on net immigration rates are reported by the state statistical agency GeoStat, but disaggregated data on flows is not available. While some smaller data collection initiatives-such as the Development on the Move survey of 2008 and periodic small-scale data collection activities of the IOM-provide more nuanced indicators of migration, they are generally not nationally representative and are infrequently conducted. As a result very little is known about contemporary migration trends in Georgia, particularly in the post-2008 period. These limitations highlight the value of eliciting insights from nationally-representative, contemporary data specifically on migration, which is done in this article using data collected in 2011/12 in both Moldova and Georgia.

The combination of lacking data and increasing visibility of migration in public discourse and policy makes investigation of the scale and composition of emigration flows particularly useful. This article explicitly explores the evolution of migration flows from Moldova and Georgia in the post-Soviet period from a gendered perspective. Migration trends from both countries are first reviewed and then placed within larger discussions of the feminisation of migration. Household survey data collected among over 12,000 individuals in Moldova and 16,000 individuals in Georgia is then explored. This article deepens understanding of how migration flows have changed since 1991 through systematic evaluation of the following five aspects of migratory movements: 1) rates of emigration from 1991 to 2010,2) changes to destination countries over time, 3) demographic characteristics of current migrants, 4) mobility patterns and reasons for migration, and 5) participation of migrants in foreign labour markets. 


\section{Background}

\section{Country contexts}

Migration flows from Moldova and Georgia must be understood within the larger changes experienced in the post-Soviet period. Following the dissolution of the Soviet Union, Moldova and Georgia, along with other former Soviet states, experienced a 'triple transition' (Offe, 1991) involving processes of market reform, nation building, and state consolidation. These transitions were often painful and protracted, creating environments in which international migration became a vital escape from poverty and civil conflict.

The immediate post-Soviet period in both Moldova and Georgia was characterized by severe contraction of economic activities and plummeting economic output as the result of movement from central planning to market economies (Svejnar, 2002). This process was accompanied by a period of economic shock following the breakdown of trading agreements concluded within the Council for Mutual Economic Assistance (de Melo, Denizer, Gelb, and Tenev, 2001). The Moldovan economy steadily declined until 2000, when gross domestic product (GDP) equated 32.2 percent of the 1989 level (Fidrmuc, 2003; Panțîru, Black, and Sabates-Wheeler, 2007). In 1994 Georgia's gross domestic product was just over one-quarter of the 1989 level (Fidrmuc, 2003), and between 1993 and August 1994, inflation rates averaged 60-70 percent per month (Papava, 2013). For both countries economic growth was negative between 1990 and 2000, with the average economic growth in that period estimated at -7.5 percent for Georgia and -9 percent for Moldova (Fidrmuc, 2003). The limited economic growth of both states coupled with the Russian economic crises contributed to a dire economic Moldovan population (IMF, 2006) and 60 percent of the Georgian population (IMF, 2003) living below the poverty line in 1999. Unsurprisingly, large-scale emigration began during the worst years of crisis.

The protracted recessions experienced by both countries occurred simultaneously with state/nation-forming processes that were tumultuous and often violent (Offe, 1991; Kuzio, 2001). In Moldova open civil war with Transnistria broke out in 1992 (Kolstø and Malgin, 1998), and despite a ceasefire concluded in the same year, the territory has remained outside of Moldovan control since (Popescu, 2005). In Georgia the early 1990s were characterized by rampant corruption, power struggles, energy outages, and lawlessness that undermined the rule of law and made state infrastructure unreliable (Wheatley, 2005; Kabachnik, 2012). Territorial conflicts over the regions of South Ossetia and Abkhazia further undermined stability. South Ossetia declared independence in 1990 and Abkhazia in 1992; despite the relatively short duration of the initial conflicts, with ceasefires declared in 1992 and 1994, respectively, the statuses of these territories have remained unresolved (Wheatley, 2005; Popescu, 2010). Russia maintained military presence in both territories since the ceasefire agreements were brokered (Borgen, 2009), and Russian backing of the government of the de facto independent South Ossetia contributed to tensions between Russia and Georgia. Periodic conflicts over the territories have undermined state consolidation efforts, most notably in 2008 when violence on the GeorgianSouth Ossetian border escalated into the "August War" between Georgia and the Russian Federation. In addition to further souring Georgian-Russian relations, the conflict resulted in the (short-term) internal displacement of an estimated 192,000 people (UNHCR, 2008) and Russia's recognition of the independence of both South Ossetia and Abkhazia (Nichol, 2008). This in turn provided the impetus for Georgia's withdrawal from the CIS in 2008. 
In both Moldova and Georgia, emigration was one response to the economic and political uncertainties of the post-Soviet period, but quantifying the scale of movement over the past two decades is a difficult process. The collapse of population registration systems and differing standards for defining and counting emigrants has made population outflow data sparse and unreliable in both countries. Given lack of agreement between statistical sources on the scale of emigration flows, the nature and composition of migration flows rather than estimations of population flows will be discussed.

In both countries, three distinct waves of emigration have occurred since 1990. The first, which immediately followed independence, was characterised by the movement of whole families who left with the intention to resettle permanently abroad. Many migrants in this era were ethnic minorities returning "home" whose initial migration had been part of centrally-organised population resettlement programmes in the Soviet period (Cantarji and Mincu, 2013; CRRC, 2007). In Georgia, territorial conflicts and nationalistic rhetoric used to promote national consolidation also promoted emigration, particularly among members of the Azeri and Armenian communities (Gugushvili, 2013). The second wave of emigration, which began in the mid-1990s, was characterised more by the emigration of individuals seeking temporary work abroad (Panțîru, Black, and Sabates-Wheeler, 2007; Gugushvili, 2013). Large spikes in emigration rates could be observed in this period, with significant population movements occurring as the result of economic shocks such as the Russian economic crisis. The third and final era, which began in the mid-2000s, has been defined by relatively stable emigration outflows and expanding emigration movements to destination countries beyond the former Soviet states (Cantarji and Mincu, 2013; Gugushvili, 2013).

The composition of migration flows and corresponding choices of destination country have changed subtly over time. Around 21.5 percent of the total population of Moldova was estimated to reside abroad in 2010, with the largest numbers living in the Russian Federation, Ukraine, Italy, and Romania (Ratha et al., 2010). Men were estimated to be 58 percent of the migrant stock in 2008 (Salah, 2008) and over 63 percent of migrant flows in 2010 (IOM, 2012). The share of men among migrants destined for countries such as Italy was much smaller, where women constituted more than 68 percent of migrants (IOM, 2012). Economic specialisation is largely responsible for these gender gaps, but the accession of Romania to the EU in 2007 (and the access to EU mobility it granted dual Moldovan/Romanian passport holders) has likely also played a role. International emigration has been an important trend for Georgia as well: by 2010 over a quarter of the population was thought to reside abroad, with the largest migrant populations in the Russian Federation, Armenia, Ukraine, Greece, and Israel (Ratha et al., 2010). Men represented a greater proportion of migrants than women in the immediate post-Soviet period, but progressively restrictive visa requirements imposed by Russia in the early 2000s (including the elimination of the visa-free travel regime in December 2000 and periodic suspensions of visa issuance to Georgians) limited opportunities for legal entry and work in Russia, the main destination for men (Hofmann and Buckley, 2013). At the same time women began entering international migration in greater numbers and constituted the largest numbers of migrants to Greece, Italy, and other countries in the EU with growing home and eldercare markets (IOM, 2009; Labadze and Tukhashvili, 2013).

The pace of migration to the EU is likely to increase given growing cooperation between both countries and the EU. Both Moldova and Georgia are members of the 
Eastern Partnership and have signed action plans with the EU in the framework of the European Neighbourhood Policy, which have included the development of mobility partnerships and visa facilitation agreements (Cantarji and Mincu, 2013; Labadze and Tukhashvili, 2013). In April 2014, visa requirements for Moldovans who hold biometric passports and wish to travel within the Schengen area were abolished, and both Moldova and Georgia signed association agreements with the EU in June 2014. Such frameworks for bilateral relations could potentially prepare both countries for future EU candidacy (Rieker, 2014). The impacts of these agreements on migration flows to the EU are unclear, but as cooperation on migration management deepens with the EU while simultaneously worsening with partners such as the Russian Federation, increased mobility to the EU would be a likely result.

\section{Feminisation of migration: theoretical linkages}

Shifting emigration patterns from Moldova and Georgia reflect broader global changes to the nature and scale of female mobility. The increased participation of women in particular migration corridors and growing demand for "female" occupations in destination countries have signalled a progressive "feminisation of migration" from certain migrant origin countries (Piper, 2007). As an analytical lens, the feminisation of migration has helped nuance understandings of the migration selection process as an inherently gendered one.

The role of gender has gradually been incorporated into theoretical frameworks that address the decision to enter international migration. Neo-classical economic theories of migrant selection largely ignored gender: migration was conceptualised as a rational decision made in response to wage differentials between sending- and receiving-countries (Harris and Todaro, 1970) or as the result of greater rewards to human capital abroad (Mincer, 1978). Labour migration was assumed to be a male phenomenon, with women viewed largely as "tied" migrants who followed male kin in their migration projects (Hill, 2004).

Economic theories of migrant selection have gradually become more inclusive of gender as the structure of labour markets in migrant-receiving countries has changed. Segmentation of labour markets by both skill level and gender has increased opportunities for women to work abroad, particularly in countries facing demographic changes. Many developed economies have experienced changes to domestic labour supply as the result of demographic changes (such as decreased availability of teenagers to take on entrylevel or low-skilled positions) that have made migrant labour an attractive way to fill employment gaps (Massey et al., 1993). The need for migrant labour-particularly female migrant labour-is particularly acute among economies with rapidly-growing elderly populations whose care needs exceed the domestic supply of caregivers.

As noted by Triandafyllidou and Marchetti (2013), domestic and care work has increasingly become a "gendered and ethnicised" economic sector (pp. 340) dominated by female migrant workers employed as live-in employees of individual households. The trend is especially apparent in Europe, where significant growth in the domestic service sector over the past ten years has attracted large volumes of migrant women. As of 2010, over 8.6 percent of all individuals in paid labour in the EU-15 region were employed in caring or cleaning occupations-an increase of more than four million workers since 2000. Countries such as Spain, Greece, and Italy experienced particularly strong growth in these occupations, particularly given increasing numbers of individual households that employ domestic personnel (Abrantes, forthcoming). 
Countries like Italy provide an excellent illustration of how the intersection among domestic economic structures, gender norms, and demographic change corroborate to create the "gendered and ethnicised" sectors to which migrant women are so attracted. The increased participation of Italian women in formal, paid employment has reduced the supply of informal caregivers within families, requiring families to find alternative, affordable care. Migrant women represent a particularly pragmatic solution in the absence of formal social protection mechanisms that address long-term elder care needs: high competition with other migrant women keeps wages low and affordable for even middle-class families, and in-home care enables the preservation of traditional familybased care models without disrupting the participation of female kin in the labour market (Bettio, Simonazzi, and Villa, 2006). The importance of migrant women as domestic and care workers is clear: by 2011, over 707,000 foreign workers were registered in the domestic and care sector in Italy alone, an increase of over 92 percent since 1994 (Castagnone, Salis, and Premazzi, 2013). In 2013 it was estimated that 1.6 million private home care workers would be hired to fill the need of Italian families, and of these hired workers, 80 percent would be foreign-born (Marchetti, 2013). The relative scarcity of workers in the home and personal care sector has resulted in increased demand for migrant women, whereas the restructuring of the economy away from labourintensive primary-sector activities such as agriculture has corresponded to saturation of the market for male migrant labour (Hondagneu-Sotelo, 2011).

Increasing economic opportunities in migrant-receiving countries may act as a particularly strong stimulus to migrate for women who have been excluded from the labour markets in their countries of origin. Despite Soviet-era policies that encouraged women to participate in the labour market and in higher education, the employment of women in formal employment across the former Soviet space has plummeted since the transition to market economies (Pollert, 2003; LaFont, 2001). In many former Soviet states, drastic reductions in social protection benefits that disproportionately benefited women and enabled their re-entry to the labour market following child birth, such as child care and maternity benefits (Bezemer, 2006), has further reduced the productivity of human capital in local labour markets. Taken together, increased opportunities for employment in female-focused sectors abroad coupled with limited economic opportunities in the home labour market may strongly encourage the participation of women in international moves, contributing to changes to the structure and composition of migration flows in the process.

\section{Methods}

\section{Data \& methodology}

Evidence of the progressive feminisation of migration from Moldova and Georgia is relatively scant, as few attempts have been made to explicitly map changes to the composition of emigration flows. This paper attempts to fill this gap with the use of detailed data on the post-Soviet mobility patterns of individuals in both Moldova and Georgia. Data were collected as part of the European Commission-funded study "the Effects of Migration on Children and the Elderly Left Behind in Moldova and Georgia" (CELBMDA/GEO). A nationally-representative household survey was conducted between September 2011 and December 2012 that collected information on the demographic 
characteristics of every household member, information on the migration histories of household members, and detailed residency histories for the years 1999-2011. Only households with one or both of the target subpopulation groups (children aged 18 or under and elderly individuals aged 60 and above) were recruited for participation in the survey.

Both surveys were drawn from a random stratified sample, with oversampling of target population groups (children, elderly, and migrants). In Moldova the sampling frame was provided by the Moldovan National Bureau of Statistics from the quarterly Moldovan labour force survey (LFS). In Georgia a sampling frame was elaborated on the basis of electoral districts, the most recently-updated, nationally-representative administrative listing in lieu of a recent census. Proportional population weights were provided following conclusion of the survey to enable extrapolation to national level. The surveys were conducted across all regions of both countries, excluding the breakaway territory of Transnistria in Moldova and the de facto independent regions of Abkhazia and South Ossetia in Georgia.

Table 1 provides an overview of the survey sample collected in both countries. Total sample numbers indicate the actual number of observations that occur in the data; weighted proportions represent the relative size of the given population when extrapolated to national level. The margin of error associated with the sample of the main characteristic of interest (migration experience) is indicated at the 95 percent confidence level.

The samples from both countries contained a significant share of individuals who had some form of migration experience, with overrepresentation of migrants especially visible in the Georgian sample. Migrants were distinguished by current versus prior residence abroad. Current migrants were individuals who were living abroad at the time of the survey and had been abroad for at least three months; return migrants were individuals who had lived abroad for three or more months but had since returned to live in the household. In both countries a greater proportion of men than women were considered migrants (either current or return), a trend that was consistent in both absolute sample numbers and weighted population percentages.

\section{Aim \& analytical method}

Given the absence of detailed and reliable data on population movements after the dissolution of the Soviet Union, the described data sets provide a unique opportunity to explore the feminisation of migration from Eastern Europe through two similar yet distinct case studies. Despite the obvious similarities between Moldova and Georgia-both are former Soviet states with ongoing economic and political transitions-differences in population characteristics and geopolitical relationships have contributed to migration flows that differ in important ways. By comparing and contrasting contemporary emigration flows from these two countries, important insights about the nature of feminised migration flows can be generated.

The aim of this paper is thus two-fold: 1) to provide a descriptive overview of how the mobility patterns of men and women have changed over time, and 2) to provide exploratory analysis of the factors that influence particular migration patterns. Descriptive statistics and bivariate means comparison tests (t-tests and analysis of variance tests) are used to explore how specific characteristics of the mobility experiences of men and women differ (or do not). Given the limited data available on the post-Soviet mobility 
Table 1 Survey sample by country

\begin{tabular}{|c|c|c|c|c|c|c|c|c|}
\hline & \multicolumn{4}{|l|}{ Moldova } & \multicolumn{4}{|l|}{ Georgia } \\
\hline & Male & Female & Total & Margin of error ${ }^{1}$ & Male & Female & Total & Margin of error ${ }^{1}$ \\
\hline Total individuals in sample & 5,801 & 6,455 & 12,256 & - & 7,320 & 8,883 & 16,203 & - \\
\hline Non migrant \% (n) & $82.7(4,800)$ & $90.1(5,818)$ & $86.64(10,618)$ & 6.01 & $82.4(6,035)$ & $84.8(7,541)$ & $83.8(13,576)$ & 5.67 \\
\hline Return migrant \% ( $n)$ & $7.8(453)$ & $4(258)$ & $5.8(711)$ & 4.14 & $4.8(353)$ & $3.2(282)$ & $3.9(635)$ & 2.98 \\
\hline Current migrant \% ( $n)$ & $9.4(548)$ & $5.8(379)$ & $7.5(927)$ & 4.66 & $12.7(932)$ & $11.9(1,060)$ & $12.3(1,992)$ & 5.05 \\
\hline Proportion in population (weighted) & 100 & 100 & 100 & - & 100 & 100 & 100 & - \\
\hline Non migrant \% & 84.3 & 91.4 & 88 & 5.75 & 91.5 & 93.1 & 92.4 & 4.08 \\
\hline Return migrant \% & 7.7 & 4.1 & 5.8 & 4.14 & 3.3 & 2.3 & 2.8 & 2.54 \\
\hline Current migrant \% & 8.05 & 4.4 & 6.2 & 4.26 & 5.2 & 4.6 & 4.8 & 3.29 \\
\hline
\end{tabular}

Source: CELB-MDA/GEO; ${ }^{1}$ Author's calculations for gender-aggregated sample based on $95 \%$ confidence level. 
patterns of both men and women, and particularly since 2008, this tactic contributes to a significant knowledge gap by mapping the major contours of migration movements.

Descriptive review is made five interrelated aspects of migration: 1) rates of emigration from 1991 to 2010,2) destination countries of new and current migrants, 3) demographic characteristics of current migrants, 4) patterns of mobility and reasons of migration of current migrants, and 5) sectors of employment of migrants working abroad.

\section{Results}

\section{Flows of new migrants over time}

The flow of emigrants leaving both Moldova and Georgia was relatively small in the immediate post-Soviet years, and in both countries a greater proportion of emigrants were men until the early-to-mid 2000s. As Figures 1 and 2 show, the number of "new migrants" (those individuals emigrating abroad for the first time) steadily increased since 1991, with the greatest proportion of new migrants leaving from Moldova in 2008 and Georgia in 2010. Moldovan women emigrated at consistently lower rates than men and have yet to constitute half of all new migrants; in 2010, the year in which the greatest proportion of women left, men still accounted for over 52 percent of all new migrants. Georgian women, in contrast, accounted for more than half of all new migrants since 2004, with the greatest proportion (nearly 64 percent) emigrating in 2007.

Despite the slower rates at which women from both countries entered migration in the early years following independence, the average rate of growth was much higher among women than men-indicating a much sharper increase in the rate at which women entered migration in later years. The later entry of women into international migration is reflected in average year of first migration: among men from both countries the average year of first migration was 2005, and for women from both countries, 2006. Such differences were significant at the .01 percent level.

\section{Migrant destination over time}

Gendered differences in migration trajectories are also clear when the destinations of new migrants over time are plotted. Figures 3, 4, 5 and 6 illustrate how the destinations

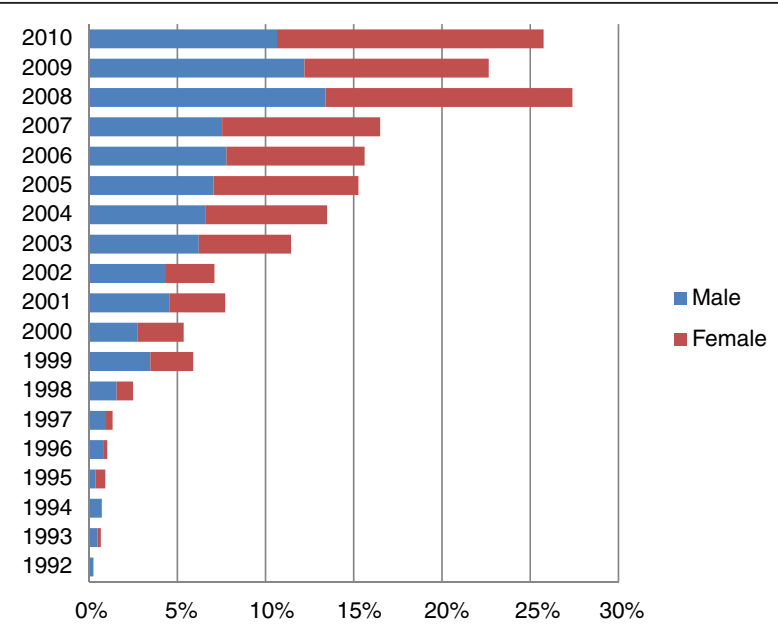

Figure 1 Proportion of new migrants from Moldova, by year \& sex. Source: CELB-MDAGEO; Author's calculations. 


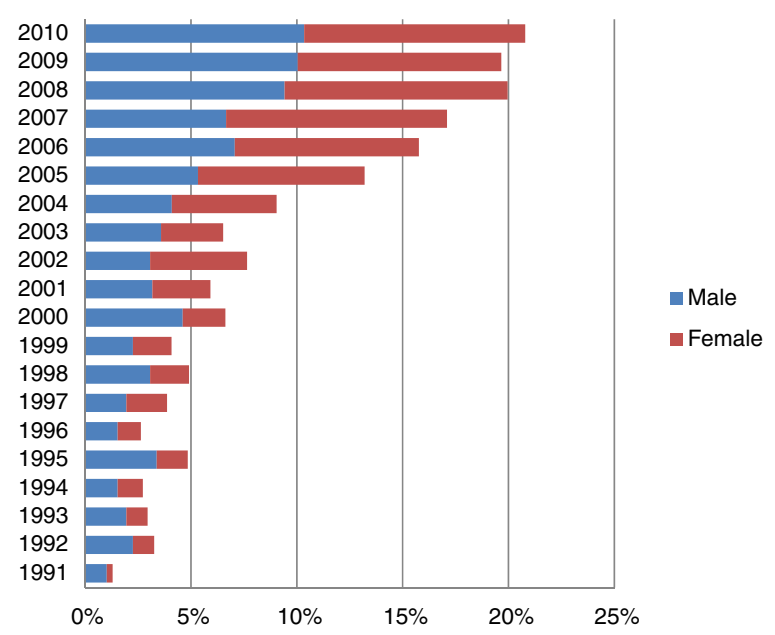

Figure 2 Proportion of new migrants from Georgia, by year \& sex. Source: CELB-MDA/GEO; Author's calculations.

of first-time migrants changed over time, with countries of destination classified into one of three regions: the Commonwealth of Independent States (CIS), the European Union (EU), and the other region (comprising all non-CIS/non-EU destinations).

Among Moldovan migrants of both genders, the main destination in the CIS region was the Russian Federation and in the EU, Italy. Main destinations in the "other" region included Canada and Israel.

With the exception of 2004, when nearly all new male Moldovan migrants left for a CIS country, around 70 percent of men in any given year since 2000 emigrated to the Russian Federation, an additional ten percent to Italy, and smaller proportions to other countries such as Canada and the Ukraine. Women, in contrast, appeared to diversify in terms of destination much earlier and to a greater extent. The earliest female migrants from Moldova, like their male counterparts, were destined primarily for the CIS, but by the mid-1990s they began emigrating in greater numbers to countries in the EU such as Italy and Spain as well as countries such as Canada. The Russian Federation

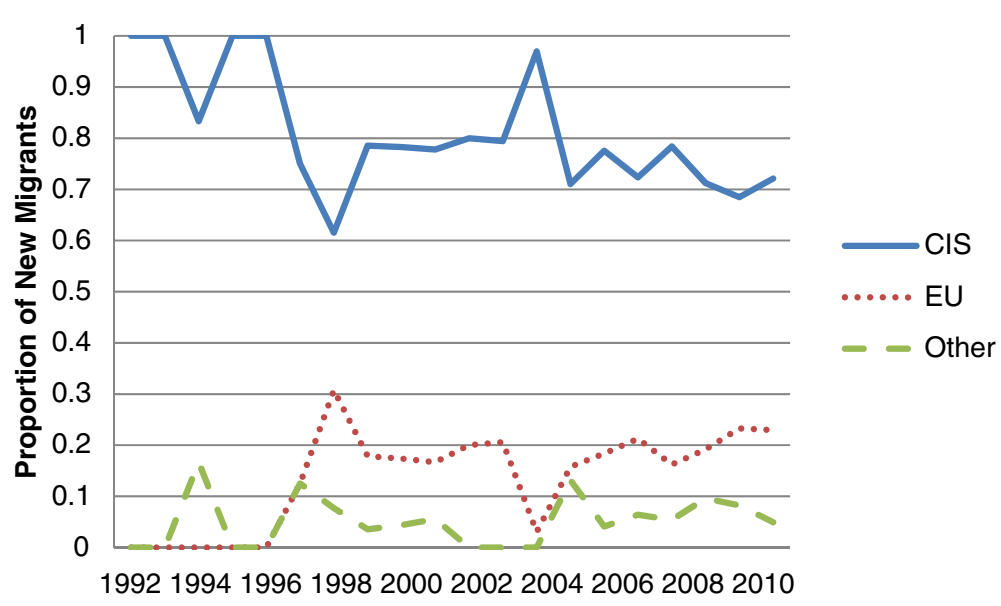

Figure 3 Destination of first migration among Moldovan men, by year. Source: CELB-MDA/GEO; Author's calculations. 


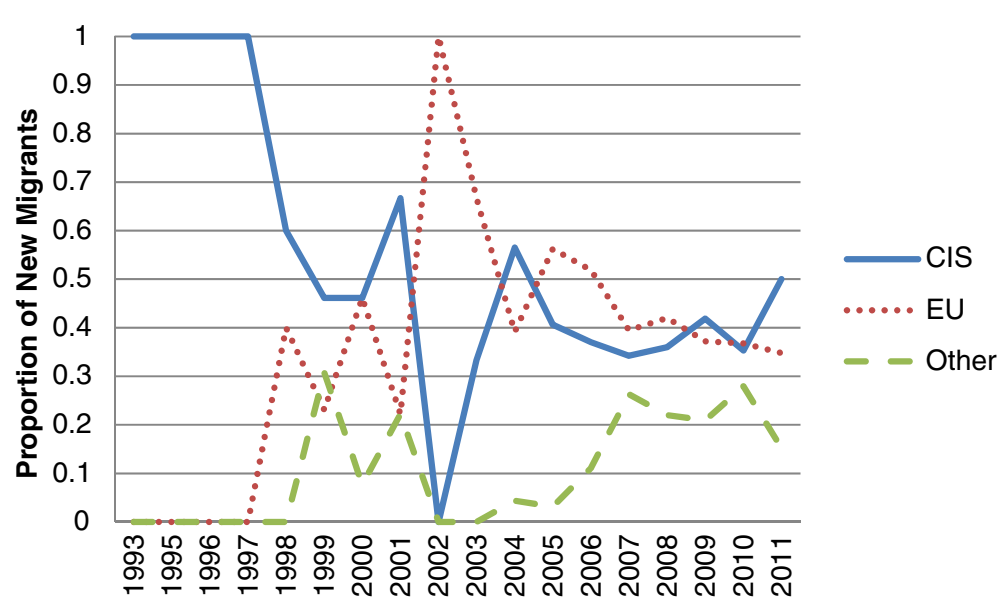

Figure 4 Destination of first migration among Moldovan women, by year. Source: CELB-MDA/GEO; Author's calculations.

and Italy consistently received the greatest proportions of new female migrants over time, but the total share of new migrants destined for any given single destination appear to be shrinking-suggesting a greater dispersion of female migrants that likely reflects increasing economic opportunities in more geographically-dispersed countries. Countries in the EU-chiefly Italy-have remained important destinations for female migrants, but emerging appealing markets such as Israel and Turkey have also begun attracting larger numbers of female migrants.

The destination patterns of Georgian migrants were similar. Among Georgian men, the CIS (namely the Russian Federation) consistently attracted over half of all emigrants leaving in every year until 2000. The EU (chiefly Greece) received the secondlargest shares of male emigrants over several years, and many other countries consistently received small shares of male migrants over time. Beginning in 2003, however, Turkey emerged as a key destination, and by 2010 nearly 40 percent of all new male emigrants were destined for Turkey. This pattern likely reflects two trends: the

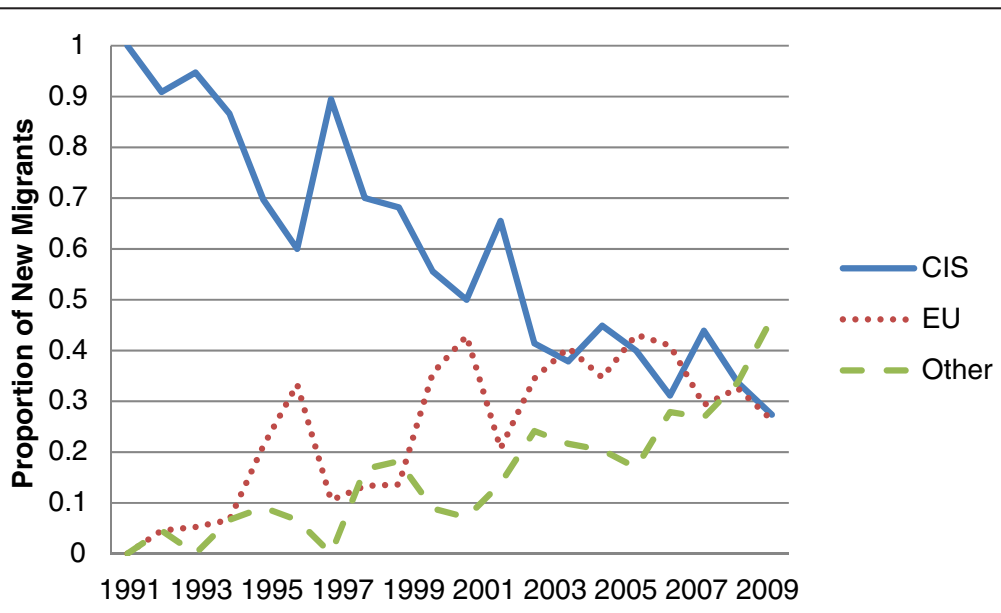

Figure 5 Destination of first migration among Georgia men, by year. Source: CELB-MDA/GEO; Author's calculations. 


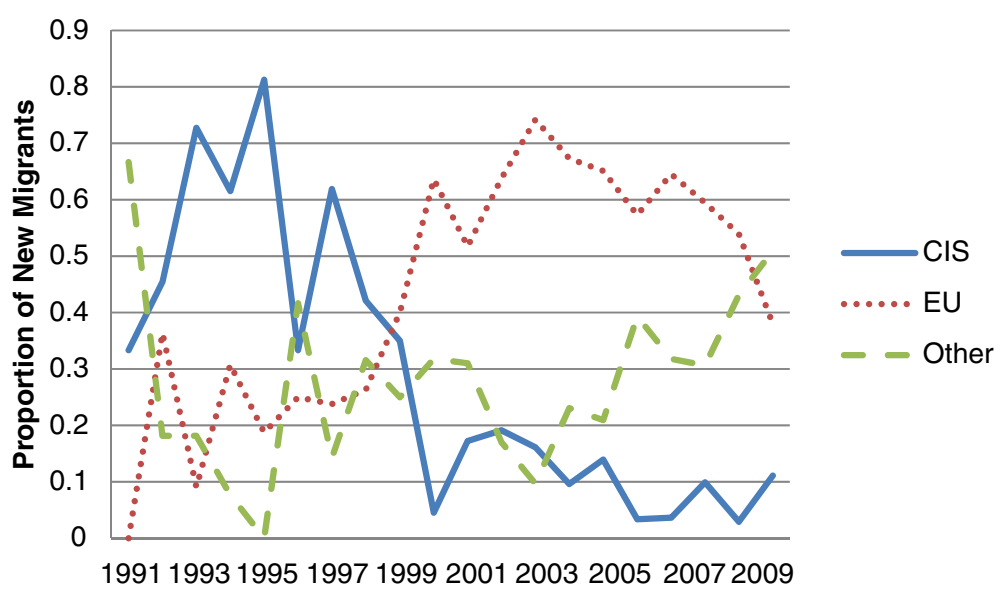

Figure 6 Destination of first migration among Georgia women, by year. Source: CELB-MDA/GEO; Author's calculations.

increasingly hostile relationship between Georgia and Russia-including the elimination of the visa-free travel regime in 2000 and periodic suspensions of visa issuance to Georgians-as well as the creation of a visa-free regime for Georgians in Turkey in 2006.

The destination patterns of Georgian women stand in stark contrast both to those of men and to those of their Moldovan female counterparts. In contrast to the other groups, which expressed strong clustering around several single destinations until the most recent years, Georgian women always emigrated to larger numbers of receiving countries. In the CIS, the Russian Federation received the greatest single proportion of Georgian women fairly consistently until 2000, but even from 1991 to 2000, other countries such as Turkey and Greece received significant shares of new emigrants (Figures 7 and 8). Since around 2003, both the EU and "other" region have attracted the greatest shares of female migrants, the largest numbers of whom were destined for Greece, Turkey, and Italy. As with Moldovan women, the destination countries to which Georgian women have increasingly emigrated are those with growing care markets.

The stocks of migrants living abroad (all migrants living abroad in 2011 regardless of year of first migration) are concentrated in specific destinations. Nearly three-quarters of all male Moldovan migrants resided in the Russian Federation at the time of the survey, with the next-largest proportion residing in Italy. Almost equal proportions of Moldovan women resided in the Russian Federation (35 percent) as Italy (32 percent), with the remaining third living in larger communities in countries such as Israel and Canada.

A much greater level of dispersion can be seen among Georgian emigrants. The largest single proportion of men (40 percent) resided in the Russian Federation at the time of the survey, with much smaller shares living in countries such as Turkey (13.8 percent) and Greece (7.9 percent). Female emigrants were slightly more dispersed, with the largest share (27 percent) residing in Greece and the next-largest share, 23 percent, residing in Turkey. Significant populations also resided in Italy and Russia, with smaller numbers split among other EU member states.

Country of destination and year of entry into international migration are naturally tied to the political and economic conditions in both home and host country. The 


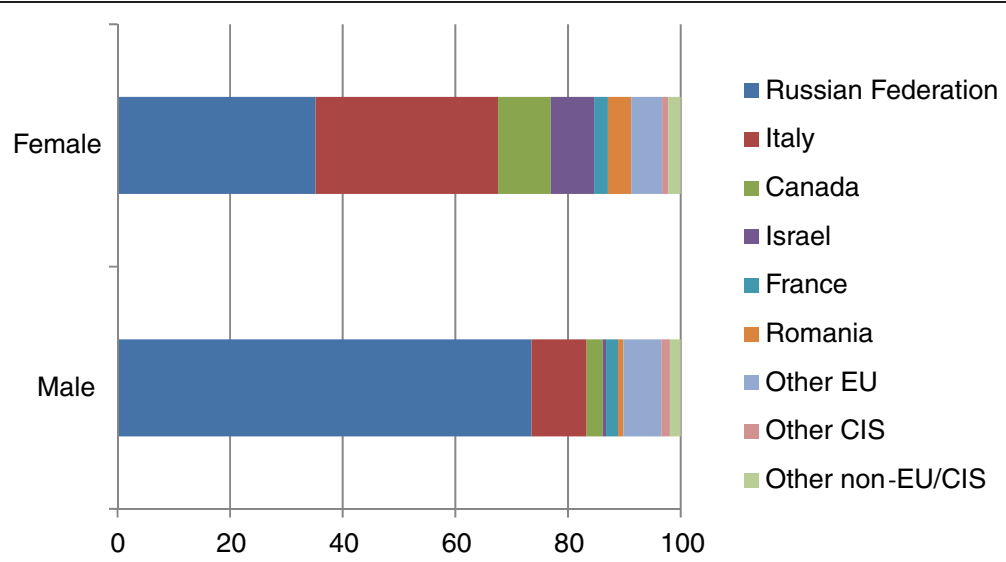

Figure 7 Proportion of current Moldovan migrants per destination, by sex. Source: CELB-MDA/GEO; Author's calculations.

limited mobility of both men and women in the early post-Soviet years reflects very particular forms of mobility-likely the "return" of ethnic Russians, Ukrainians, Greeks, etc. to ancestral homelands as well as the migration of an elite group who had both the means and motivation to emigrate further abroad. Increased rates of emigration in the mid-to-late-1990s likely reflects individuals going abroad to find employment in the midst of severe and protracted economic stagnation, which peaked in the late 1990s-particularly in Moldova-in response to the Russian financial crisis. Given the relatively high cost of emigrating to destinations further abroad, it is unsurprising that most migration during this time was to neighbouring countries.

The increasing rate of female entry into international migration in the $2000 \mathrm{~s}$ is a likely function of shrinking economic opportunities in the home country as well as the growth of gender-segmented labour markets in receiving countries (Table 2). The relatively early diversification of women and the greater geographical dispersion of women compared to men corresponded to changes in the economic opportunities for both genders that were either promoted or stymied by political relationships.

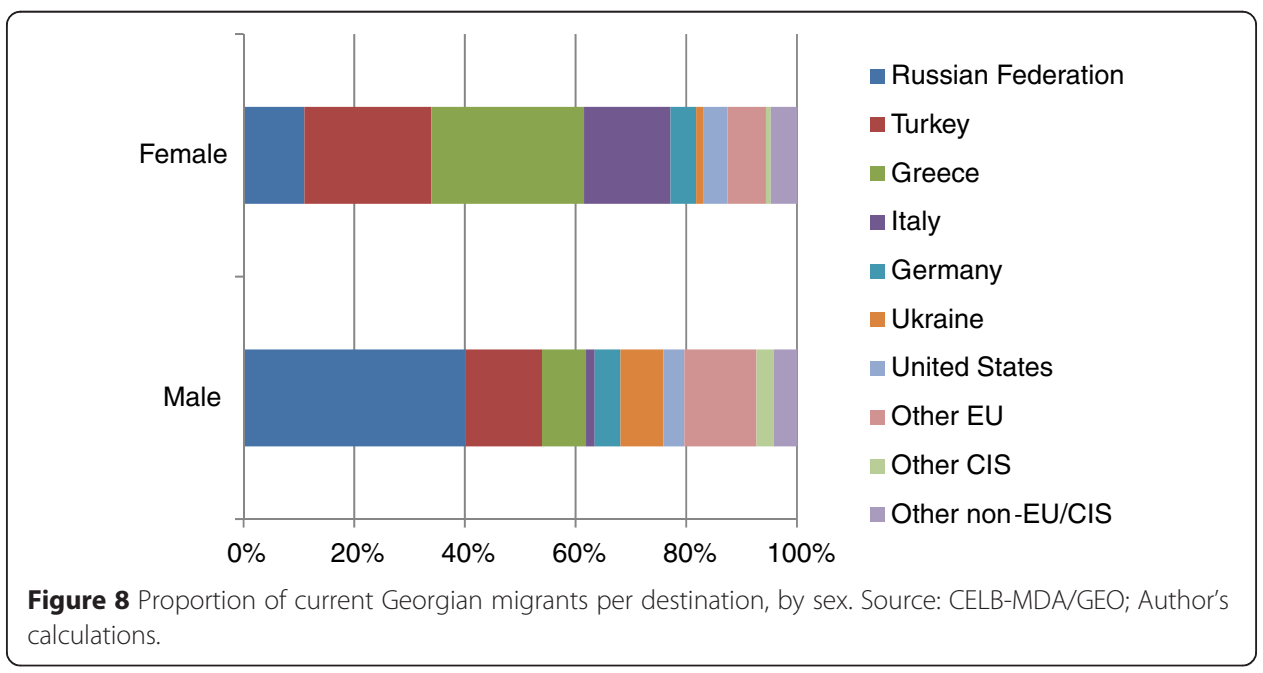




\section{Demographic characteristics of current migrants}

Migrants are unlikely to be randomly selected from among the general population and would be expected to differ from non-migrants based on both observable and unobservable personal characteristics such as age and education level. Given differences in the secondary selection of migrants into specific destination countries, male and female current migrants would also be expected to differ from one another. Comparison of the "average" characteristics of both male and female current- and non-migrants suggests that the populations differ significantly from one another in important ways.

In Moldova, female migrants were significantly younger than their non-migrant counterparts, whereas for men, age did not differ significantly between migrant and non-migrant populations. Both male and female current migrants from Georgia were significantly older than their non-migrant counterparts, with the difference particularly marked among Georgian men. Migrant populations of both sexes and from both countries had completed significantly more years of education than had non-migrants, and in both countries female current migrants had completed more years of education than male migrants. This may suggest that the relatively better-

Table 2 Demographic characteristics of migrants and non-migrants, by sex

\begin{tabular}{|c|c|c|c|c|c|c|c|}
\hline & \multicolumn{3}{|l|}{ Male } & \multicolumn{3}{|l|}{ Female } & \multirow[b]{2}{*}{$\begin{array}{l}\text { Difference, } \\
\text { sex }\end{array}$} \\
\hline & $\begin{array}{l}\text { Non- } \\
\text { migrant }\end{array}$ & $\begin{array}{l}\text { Current } \\
\text { migrant }\end{array}$ & $\begin{array}{l}\text { Difference, } \\
\text { migration } \\
\text { status }\end{array}$ & $\begin{array}{l}\text { Non- } \\
\text { migrant }\end{array}$ & $\begin{array}{l}\text { Current } \\
\text { migrant }\end{array}$ & $\begin{array}{l}\text { Difference, } \\
\text { migration } \\
\text { status }\end{array}$ & \\
\hline \multicolumn{8}{|l|}{ MOLDOVA } \\
\hline Age & 33.7 & 34.2 & & 37.6 & 36.5 & & $* *$ \\
\hline Age at first migration & - & 29.8 & - & - & 31.9 & - & $* * *$ \\
\hline Years of education & 9.2 & 10.8 & $* * *$ & 9.1 & 11.3 & $* * *$ & $* *$ \\
\hline $\begin{array}{l}\text { Number of children } \\
\text { in household }\end{array}$ & 1.39 & 1.14 & $* * *$ & 1.3 & 1.18 & * & \\
\hline $\begin{array}{l}\text { Number of elderly } \\
\text { persons in household }\end{array}$ & 0.34 & 0.19 & $* * *$ & 0.38 & 0.26 & $* * *$ & * \\
\hline \multicolumn{8}{|l|}{ Marital status (\%) } \\
\hline Married & 63.9 & 70.5 & * & 57.3 & 60.8 & & $* *$ \\
\hline Never married & 27.8 & 25.9 & & 18.3 & 18.9 & & * \\
\hline Widowed & 5.57 & 0.5 & $* * *$ & 19.9 & 6.13 & $* * *$ & $* * *$ \\
\hline Divorced & 2.72 & 2.97 & & 4.3 & 14.1 & $* * *$ & $* * *$ \\
\hline \multicolumn{8}{|l|}{ GEORGIA } \\
\hline Age & 34.38 & 40.10 & $* * *$ & 39.5 & 42.7 & $* * *$ & $* * *$ \\
\hline Age at first migration & - & 32.4 & - & - & 37.7 & - & $* * *$ \\
\hline Years of education & 10.74 & 12.73 & $* * *$ & 11.07 & 12.94 & $* * *$ & \\
\hline $\begin{array}{l}\text { Number of children } \\
\text { in household }\end{array}$ & 1.31 & .90 & $* * *$ & 1.21 & .95 & $* * *$ & \\
\hline $\begin{array}{l}\text { Number of elderly } \\
\text { persons in household }\end{array}$ & .56 & .62 & * & .58 & .53 & * & * \\
\hline \multicolumn{8}{|l|}{ Marital status (\%) } \\
\hline Married & 70.19 & 72.41 & & 56.98 & 50.05 & $* * *$ & $* * *$ \\
\hline Never married & 24.18 & 23.45 & & 16.05 & 20.85 & $* * *$ & \\
\hline Widowed & 4.29 & 1.31 & $* * *$ & 22.52 & 13.74 & $* * *$ & $* * *$ \\
\hline Divorced & 1.34 & 2.84 & $* * *$ & 4.45 & 15.37 & $* * *$ & $* * *$ \\
\hline
\end{tabular}

Source: CELB-MDA/GEO; Author's calculations. Significance: ${ }^{* * *} p<0.001,{ }^{* *} p<0.01,{ }^{*} p<0.05$. 
educated members of the population are incentivized to migrant, either because of better productivity of education abroad or because of the differences in personal attitudes and capacities associated with better education. At the same time, the differences between men and women likely reflects differences in the sectors in which male and female migrants work abroad, with men working in industries such as construction and manufacturing where education may not increase their competitiveness.

Other personal characteristics, such as family or household composition, are likely to also influence whether an individual will select into migration and, if so, to where. In both countries, current migrants resided with a smaller number of children than did non-migrants, and this difference was highly significant for all groups in both countries. Migrants from Georgia appeared to be particularly dissuaded from migrating with the presence of children in the household, which may reflect the relatively greater distance migrants would have to travel to find a suitable destination labour market (with the exception of neighbouring countries such as Turkey, which has become accessible and desirable only relatively recently). Residing with a greater number of elderly individuals also seemed to discourage female migrants from both countries and male migrants from Moldova.

Marital status differed significantly between men and women and between migrant and non-migrant populations. In both countries marital status appeared to be only weakly correlated to male migration, with few marital statuses proving significantly different between migrant and non-migrant populations. Among women, however, significant differences by marital status were clear. In both Moldova and Georgia, a smaller proportion of the current migrant population was widowed compared to the non-migrant population, but a much larger proportion of current migrants were divorced (Table 3). The proportion of female current migrants who were divorced was three times that of the non-migrant population, suggesting that there is a strong relationship between marriage dissolution and migration that levies a much stronger influence on women than men ${ }^{\mathrm{a}}$.

\section{Mobility patterns of current migrants}

Demographic characteristics of the migrant samples as well as differing contexts in destination countries would be expected to differentially impact the mobility patterns of men and women.

The average amount of time migrants resided abroad between 1999 and 2010 differed considerably by destination region but seldom differed significantly between the sexes, with only Moldovan male and female migrants residing in the CIS found to have significantly-different average lengths of stay.

More significant differences between the sexes appeared in the type of migration and return pattern. In both Moldova and Georgia, fewer women than men were consider circular or seasonal migrants. Among Moldovan migrants this difference was significant for migrants in the CIS region, where over 74 percent of men were considered circular/seasonal migrants compared to 63.5 percent of female migrants. In Georgia the significant difference appeared among migrants to the $\mathrm{EU}$, where 7.5 percent of men compared to 3.6 percent of women were considered circular/seasonal migrants. These differences likely reflect seasonality of male-dominated occupations such as construction and agriculture. A larger share of Moldovan women than men residing in the EU returned once per year, and more women 
Table 3 Characteristics of current migrants' mobility patterns, by sex

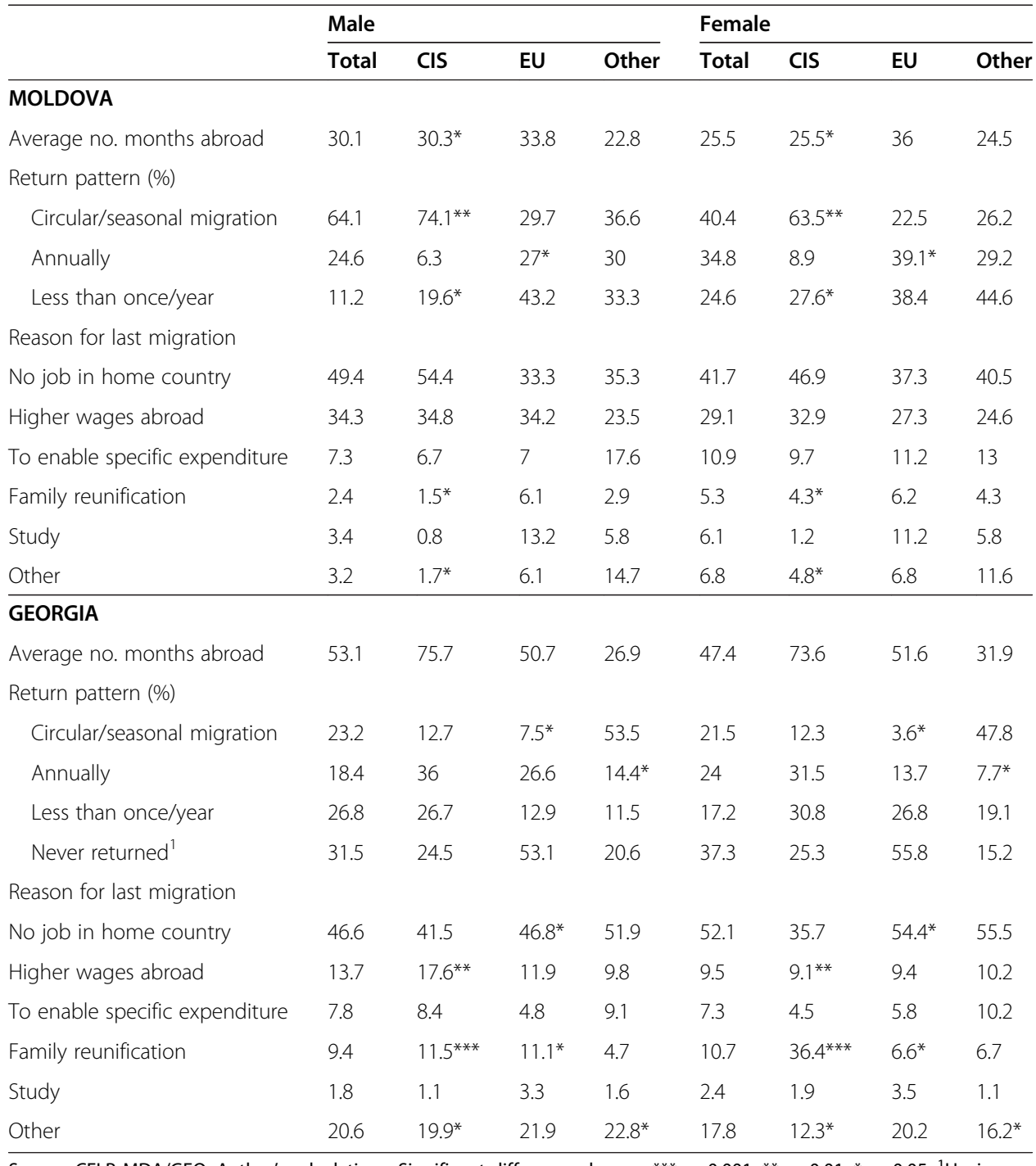

Source: CELB-MDA/GEO; Author's calculations. Significant differences by sex: ${ }^{* *} p<0.001,{ }^{* *} p<0.01,{ }^{*} p<0.05$. ${ }^{1}$ Having not yet returned was an answer option only in the Georgian survey.

than men residing in the CIS returned less than once a year. Among Georgians fewer women than men residing in a country in the "other" region returned at least once a year.

The decision to migrate the last time also differed between men and women and by destination region. In both countries the largest single shares of emigrants of both sexes left because of an absence of a job in the home country. Among Moldovans, the second-largest share of migrants left because of the wage differentials between employment opportunities in the local and foreign labour market, reinforcing the strongly economic nature of Moldovan migration. In contrast, the second-largest shares of Georgian migrants emigrated for other reasons, such as fleeing conflict or seeking a "better way" of life abroad. Marked differences can be seen by destination, however, but relatively few differences between men and women were significant. Among both Moldovan and Georgia migrants to the CIS, a smaller share of men than women emigrated for family reunification purposes, but among Georgian migrants to the EU, a 
larger share of men than women emigrated on the grounds of family reunification. This may signal that women to particular destinations are increasingly becoming the 'pioneer' migrants whom men then follow as 'trailing' spouses or children.

\section{Employment abroad}

Differences between men and women in destination choice and personal characteristics correspond to marked differences in the sectors of employment of men and women. The largest single share of Moldovan men in each destination region worked in the construction sector, with nearly three-quarters of all Moldovan men in the CIS region working in construction. Smaller shares of men worked in the hospitality industry (in hotels and restaurants) or in the manufacturing sector, and in the "other" region, larger shares of men worked in social or personal service occupations. Moldovan women, in contrast, were more evenly distributed among a larger number of occupational sectors across destination regions. Nearly 40 percent of female migrants in the CIS worked in construction, whereas in the EU and 'other' regions, over 40 percent of all female migrants worked for individual household employers. Relatively large shares of women in the CIS worked in wholesale or retail trade, and larger shares worked in the transport and telecommunications sector as well as in social and personal services in both the EU and 'other' regions.

Differing occupational distributions of Georgian migrants can be seen by destination region (Figures 9 and 10). The largest share of men in all regions worked in the construction sector, but a much larger share of men in the CIS region (over 40 percent) worked in construction compared to men in the EU and 'other' regions. A similar share of men in all regions (between ten and 11 percent) worked for individual household employers, and significant shares also worked in the manufacturing sector (where over 20 percent of men in the 'other' region worked). In the 'other' region, a relatively share of men (over 15 percent) worked in the agriculture sector, more than in the CIS or EU. In contrast, the majority of women across all destinations worked in an 'other' sector, a category encompassing a range of sectors (such as education, healthcare, and banking) in which small numbers of respondents worked. The second-largest single shares of women in the EU and 'other' region worked for individual household employers: over 42 percent of women in the $\mathrm{EU}$ and 34 percent in the 'other' region worked as caregivers or cleaning staff for individual households. In the CIS region, very small shares of women worked for individual households, but relatively larger shares worked in manufacturing (18.2 percent), wholesale/retail (14.5 percent), and hospitality (15.6 percent).

\section{Conclusions}

Observed patterns of emigration from Moldova and Georgia between 1991 and 2010 provide evidence of a progressive feminisation of migration. As noted by (Piper, 2007), the term encompasses four interrelated phenomena: increased participation of women in migration streams, improved visibility of female migrants in statistics, male un- and under-employment in origin countries, and increased demand for "feminised" jobs in destination countries (Piper, 2007). Many of these trends can be observed in both Moldova and Georgia, where increased movements of women internationally have 


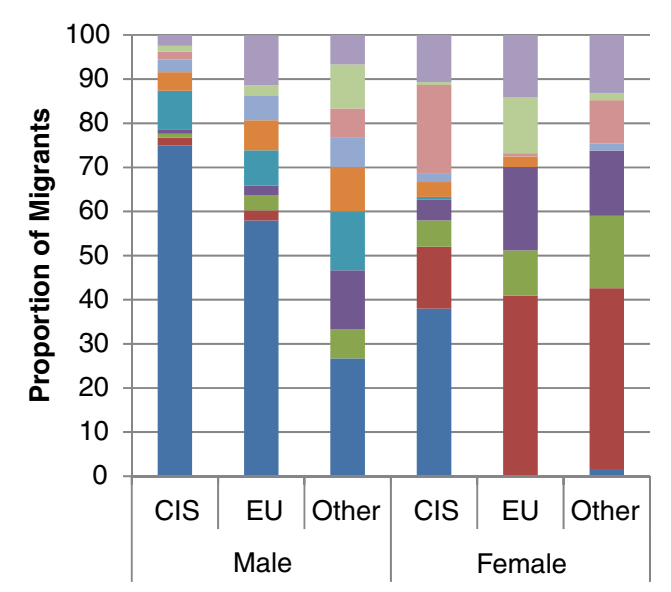

- Other

Security services

Wholesale/retail

Agriculture

Manufacturing

- Hospitality

- Social/personal services

- Transport \& Telecom

- HH Employment

- Construction

Figure 9 Moldovan current migrant sector of employment, by sex. Source: CELB-MDA/GEO; Author's calculations.

corresponded with larger shifts in the demands of receiving country labour markets simultaneously toward migrant women and away from migrant men.

Based on the descriptive overview of migration trends within the CELB-MD/GE dataset, several specific observations about the gender dimension of migration from Moldova and Georgia can be made. The first is that despite the later entry of women into international migration, the rate of increase among women participating in international moves was greater than among men. This suggests that incentives or opportunities to move were relatively more consistent for men over time than they were for women, with the entrance of women into international migration coinciding with larger changes to migration regimes and labour market demands that favoured female mobility.

The second observation is that despite the relationship between the structure of labour markets in receiving countries and female migration, women have expressed a greater diversity of emigration patterns-in terms of destination countries, reasons for migration, and sectors of employment-than have men. Male migrants were concentrated in both a smaller number of destination countries and in a smaller number of

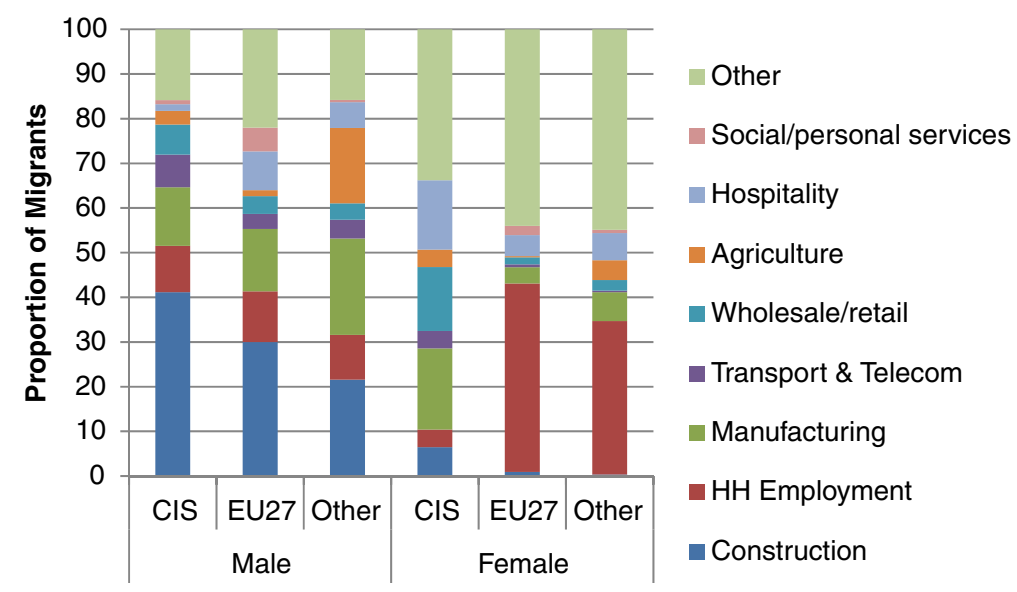

Figure 10 Georgian current migrant sector of employment, by sex. Source: CELB-MDAGEO; Author's calculations. 
sectors than women were, suggesting relatively more rigid migration trajectories that encouraged economic specialisation. The continual, relatively unencumbered access of Moldovan men to the Russian labour market, for instance, has provided little incentive to diversify, even throughout times of financial crisis. Increasing need for domestic workers in countries as dispersed as Canada, Italy, Turkey, and Israel have implied that women have faced opportunities to disperse as well. At the same time, women are not exclusively limited to work in the domestic and care sector. In contrast to men, who worked largely in the construction and manufacturing sectors regardless of destination, smaller shares of women worked in a larger number of sectors across destinations. Taken together, these observations indicate that-while women's mobility increased in conjunction with demographic and economic transitions in primary destination countries-the economic niches in which women function may not be as narrow as they are for men.

The patterning of migration flows is naturally a nuanced process informed not only by singular "push" or "pull" factors but of the coalescence of many factors over time. Labour market opportunities abroad provide only one set of explanations for increasing female migration; other political, economic, and cultural transitions provide yet others. A growing body of work specifically on the dynamics of east-west female migration has started to unpack some of these complex linkages. (Marchetti and Venturini 2013), for instance, have explored how the mobility patterns and occupational choices of Ukrainian and Moldovan women in Italy are influenced by their ages at emigration, corresponding roles within families (as mothers or grandmothers), and socioeconomic environments in the home country. Others, such as (Hofmann and Buckley 2013) have explored how migrant women strategically construct narratives of migration that justify female mobility as a sacrifice made to ensure the well-being of the household, which helps reconstitute or reinforce traditional gender roles amid economic transition. As just two examples among many, these works highlight how larger gendered contexts influence individual mobility. Such micro-level approaches to understanding larger social phenomenon complement more macro-level of approaches to mapping migration flows such as this.

The analysis of macro-level migration trends, particularly over the turbulent postSoviet period, provides important insight into the dynamic nature of personal mobility. The composition and scale of emigration flows from both Moldova and Georgia have changed markedly over the past two decades, largely in response to economic needs but also to political constraints and opportunities. The cross-country comparison signals both commonalities and points of divergence, yet one overarching trend that is likely to apply to other former Soviet states appears: that the feminisation of migration has begun, and the former Soviet space may be one of its most pertinent frontiers.

\section{Endnote}

${ }^{a}$ Multivariate analyses modelling the migration propensities of men and women using logit probability models has confirmed that marital status is differentially significant in the migration projects of men and women. See Vanore, Siegel, and Mazzucato (forthcoming) for additional detail.

Competing interests

The authors declare that they have no competing interests. 


\section{References}

Abrantes, M. (Forthcoming). Yes, but What About Numbers? A Quantitative Contribution to the Study of Domestic Services in Europe. International Labour Review (postprint). doi:10.1111/j.1564-913X.2012.00004.X

Bettio, F, Simonazzi, A, \& Villa, P. (2006). Change in Care Regimes and Female Migration: the 'Care Drain' in the Mediterranean. Journal of European Social Policy, 16(3), 271-285.

Bezemer, DJ. (2006). Poverty in Transition Countries. Journal of Economics and Business, 9(1), 11-35.

Borgen, CJ. (2009). The language of law and the practice of politics: great powers and the Rhetoric of selfdetermination in the sases of Kosovo and South Ossetia. Chicago Journal of International Law, 10(1), 1-34.

Cantarji, V, \& Mincu, G. (2013). Costs and Benefits of Labour Mobility Between the EU and the Eastern Partnership Countries. Country Report: Moldova. Report for project EuropeAid/130215/C/SER/Multi.

Castagnone, E, Salis, E, \& Premazzi, V. (2013). Promoting Integration for Migrant Domestic Workers in Italy. International Migration Paper No. 115. Geneva: International Labour Office, International Migration Programme, International and European Forum of Research on Immigration.

Caucasus Research Resource Centres (CRRC) Georgia. (2007). Migration and Return in Georgia: Trends, Assessments, and Potential. Project reported submitted to the Danish Refugee Council within the project "Toward Durable Reintegration Mechanisms in Georgia".

de Melo, M, Denizer, C, Gelb, A, \& Tenev, S. (2001). Circumstance and choice: The role of initial conditions and policies in transition economies. The World Bank Economic Review, 15(1), 1-31.

Fidrmuc, J. (2003). Economic reform, democracy, and growth during post-communist transition. European Journal of Political Economy, 19, 583-604

Gugushvili, A. (2013). CARIM-East Research Report 2013/29. Institute: European University. The Development and the Side Effects of Remittances in the CIS Countries and Georgia: the Case of Georgia.

Harris, JR, \& Todaro, MP. (1970). Migration, unemployment, and development: A two-sector analysis. The American Economic Journal, 60, 126-142.

Hill, LE. (2004). Connections between U.S. female migration and family formation and dissolution. Migraciones Internacionales, 2(3), 60-82.

Hofmann, ET, \& Buckley, CJ. (2013). Global changes and gendered responses: the feminization of migration from Georgia. International Migration Review, 47, 508-538. doi:10.1111/imre.12035.

Hondagneu-Sotelo, P. (2011). Gender and migration scholarship: an overview from a $21^{\text {st }}$ century perspective. Migraciones Internacionales, 6(1), 219-233.

International Monetary Fund. (2003). Republic of Moldova: Poverty Reduction Strategy Annual Evaluation Report 2005. Washington, D.C: IMF Country Report No. 06/185. IMF.

International Monetary Fund. (2006). Georgia: Poverty Reduction Strategy Paper. Washington, D.C: IMF Country Report No. 03/265. IMF.

International Organisation for Migration (IOM). (2009). Testing New Channels and Products to Maximise the Development Impact of Remittances for the Rural Poor in Georgia: Tianeti Household Census 2008 \& Tianeti Emigrants to Greece 2008 Fieldwork Report. IOM: Georgia.

International Organisation for Migration (IOM). (2012). Extended Migration Profile of the Republic of Moldova. IOM Moldova: Chisinau.

Kabachnik, P. (2012). Shaping Abkhazia: cartographic anxieties and the making and remaking of the Abkhazian Geobody. Journal of Balkan and Near Eastern Studies, 14(4), 397-415.

Kolstø, P, \& Malgin, A. (1998). The Transnistrian republic: a case of politicized regionalism. Nationalities Papers: The Journal of Nationalism and Ethnicity, 26(1), 103-127.

Kuzio, T. (2001). Transition in post-communist states: triple or quadruple? Politics, 21(3), 168-177.

Labadze, L, \& Tukhashvili, M. (2013). Costs and Benefits of Labour Mobility Between the EU and the Eastern Partnership Countries: Georgia Country Study. Report for project EuropeAid/130215/C/SER/Multi.

LaFont, S. (2001). One step forward, two steps back: women in the post-communist states. Communist and Post-Communist Studies, 34, 203-220.

Makaryan, S. (2012). Estimation of International Migration in Post-Soviet Republics. International Migration (early view published online before inclusion in an issue). doi:10.1111/j.1468-2435.2012.00740.x.

Marchetti, S. (2013). Dreaming circularity? Eastern European women and jobs sharing in paid home care. Journal of Immigrant and Refugee Studies, 11(4), 347-363. doi:10.1080/15562948.2013.827770.

Marchetti, S, \& Venturini, A. (2013). Mothers and Grandmothers on the. Move: Labour Mobility and the Household Strategies of Moldovan and Ukrainian Migrant Women in Italy. International Migration. doi:10.1111/imig.12131

Massey, DS, Arango, J, Hugo, G, Kouaouci, A, Pellegrino, A, \& Taylor, JE. (1993). Theories of International migration: a review and appraisal. Population and Development Review, 19(3), 431-466.

Mincer, J. (1978). Family migration decisions. Journal of Political Economy, 86, 749-773.

National Bureau of Statistics of the Republic of Moldova (NBS) (2012). Population and Demography Metadata. Guide to statistical indicators. Available on the NBS website at http://www.statistica.md/public/files/Metadate/en/ Populatia_en.pdf. Accessed 10 July, 2013.

Nichol, J. (2008). Russia-Georgia Conflict in South Ossetia: Context and Implications for U.S. Interests. United States Congressional Research Service report. Accessed 11 July, 2013 from http://www.dtic.mil/cgi-bin/GetTRDoc?Location= U2\&doc=GetTRDoc.pdf\&AD=ADA490073

Offe, C. (1991). Capitalism by democratic design? Democratic theory facing the triple transition in East Central Europe. Social Research, 58(4), 865-892.

Pantîru, MC, Black, R, \& Sabates-Wheeler, R. (2007). Migration and poverty reduction in Moldova. University of Sussex Development Research Centre on Migration, Globalisation, and Poverty Working Paper C10.

Papava, V. (2013). Reforming of the Post-Soviet Georgia's Economy in 1991-2011. GFSIS Center for Applied Economic Studies Research Paper. Georgian Foundation for Strategic International Studies: Tbilisi. Accessed online 26 July, 2013 from: http://gfsis.org/media/download/library/articles/papava/Papava_Reforming_of_the_Post-Soviet_Georgia_ Economy_in_1991-2011.pdf 
Piper, N. (2007). International Migration and Gendered Axes of Stratification-Introduction. In N Piper (Ed.), New Perspectives on Gender and Migration: Livelihoods, Rights, and Entitlements (pp. 1-34). Routledge: Oxon.

Pollert, A. (2003). Women, work and equal opportunities in post-communist transition. Work, Employment and Society, $17(2), 331-357$.

Popescu, N. (2005). The EU in Moldova: Settling Conflicts in the Neighbourhood. Paris: The European Union Institute for Security Studies Occasional Paper No. 60

Popescu, N. (2010). The EU and Civil Society in the Georgian-Abkhaz Conflict. MICROCON Policy Working Paper No. 15. Brighton: MICROCON: A Micro Level Analysis of Violent Conflict, Institute of Development Studies, University of Sussex.

Ratha, D, Mohapatra, S, \& Silwal, A. (2010). Migration and Remittances Factbook 2011. World Bank.

Rieker, P. (2014). Importance of the European Neighbourhood Policy: A Role for Norway? Policy Brief 1/2014. Norwegian Institute of International Affairs: Oslo.

Salah, MA. (2008). The Impacts of Migration on Children in Moldova. United Nations Children's Fund Working Paper. New York: United Nations Children's Fund, Division of Policy and Practise.

Svejnar, J. (2002). Transition economies: performance and challenges. Journal of Economic Perspectives, 16(1), 3-28.

Triandafyllidou, A, \& Marchetti, S. (2013). Migrant domestic care wokers in Italy: new patterns of circulation? Journal of Immigrant and Refugee Studies, 11(4), 339-346. doi:10.1080/15562948.2013.822750.

United Nations High Commissioner for Refugees (UNHCR) (2008). "Revised Figures Push Number of Georgia Displaced up to 192,000." News bulletin published 12 September, 2008. Available from online archive at http:// www.unhcr.org/48ca8d804.html

Wheatley, J. (2005). Georgia from National Awakening to Rose Revolution: Delayed Transition in the Former Soviet Union. United Kingdom: Ashgate Publishing Limited, Hampshire.

\section{Submit your manuscript to a SpringerOpen ${ }^{\circ}$ journal and benefit from:}

- Convenient online submission

- Rigorous peer review

- Immediate publication on acceptance

- Open access: articles freely available online

- High visibility within the field

- Retaining the copyright to your article 